\title{
KEDAI KOPI DAN KOMUNITAS SENI SEBAGAI WUJUD RUANG PUBLIK MODERN
}

\author{
Eka Perwitasari Fauzi \\ Fakultas Ilmu Komunikasi Universitas Mercu Buana \\ Email : eka.perwitasari@ mercubuana.ac.id
}

\begin{abstract}
Abstrak
This paper is based on research on coffee shops as a modern public space in the information age. This study tries to examine the existence of modern public space in the form of social communities along with more coffee shop emerges as new business trends in Jakarta. One of many coffee shop business is Kedai Suguh Kopi in the West Jakarta Region. In contrast to the concept of a cafe, or a coffee shop which mostly serves only coffee and stunning interior design that might lurks customer for their so-called "instagramable", one interesting thing about this shop is that coffee is not served to release the sleepy feeling but it witness and become a reason of the birth of an art community that contains freedom of expression without pressure.
\end{abstract}

Keywords : public spaces, habermas, coffee shops

\section{A. PENDAhUluan}

Tulisan ini disusun berdasarkan penelitian mengenai kedai kopi sebagai bentuk ruang publik modern di era informasi. Penelitian ini mencoba mengkaji keberadaan ruang publik modern dalam bentuk komunitas sosial yang tercipta seiring tumbuhnya sebuah kedai kopi di perkotaan Jakarta, salah satunya adalah Kedai Suguh Kopi di Kawasan Jakarta Barat. Berbeda dengan konsep cafe, ataupun kedai kopi yang pada umumnya hanya mengedepankan konsep cafe house (hanya untuk minum kopi) dengan desain interior yang menarik dan instagramable bagi para pengunjungnya, satu hal menarik dari kedai ini adalah kopi tidak hanya sekedar disuguhkan untuk penghilang kantuk, namun, menjadi alasan lahirnya sebuah komunitas seni yang di dalamnya terdapat kebebasan berekspresi tanpa tekanan.

Budaya minum kopi di Indonesia sudah berkembang sejak lama, sejak pertama kali sistem tanam paksa oleh pemerintahan Belanda pada tahun 1830, seiring berkembangnya masyarakat Indonesia pun mulai gemar meminum kopi. Pada awalnya minum kopi hanya dilakukan oleh orang dewasa hingga usia lanjut dan didominasi oleh pria. Namun, dengan berkembangnya jaman, budaya minum kopi mulai banyak digemari tidak saja orang tua atau pria, namun anak muda dan juga wanita. 
Minum kopi juga tidak hanya sekadar untuk menghilangkan kantuk. Budaya minum kopi menjadi tren dan lifestyle baru bagi kalangan anak muda. Jika di negara barat, minum kopi di kedai-kedai kopi adalah hal yang biasa, ketika sampai di Indonesia, minum kopi dan berbincang dengan teman, keluarga, rekan kerja, bahkan bagi beberapa orang, menjamu klien dan rapat juga sering dilakukan di kedai-kedai kopi.

Banyak orang berlama-lama duduk di kedai kopi. Bagi penikmat kopi, kualitas kopi menjadi alasan pemilihan. Namun, bagi orang awam ada begitu banyak alasan kenapa mereka memilih untuk duduk dan minum kopi. Terlebih bagi generasi milennial yang didominasi oleh anak muda dengan range usia 18-40, ada banyak sebab kenapa mereka memilih kedai kopi untuk bersosialisasi.

Kemunculan kedai-kedai kopi di Indonesia, khususnya Jakarta, juga menjadi pendorong begitu populernya budaya minum kopi ini. Yang menarik dari fakta ini adalah fakta bahwa banyak anak muda yang memutuskan untuk terjun ke bisnis ini.

Di Jakarta khususnya, ada begitu banyak kedai kopi bermunculan dengan menawarkan berbagai konsep minum kopi. Namun, mayoritas menawarkan desain interior fisik dengan tujuan mendapatkan label "instagramable" yaitu tempat menarik sebagai objek fotografi sehingga akan terlihat cantik ketika dipublikasi dalam media sosial instagram. Miris karena kemudian yang dijual bukan lagi mengenai kopinya tapi label tadi. Muhajir Al Fairusy dalam artikelnya "Public Sphere dalam Secangkir Kopi” mengatakan bahwa interaksi yang dibangun dalam sebuah kedai kopi adalah budaya lisan, karena pengunjung kedai kopi mengutamakan komunikasi tatap muka, mengutakan ruang sosial dengan mengandalkan pendengaran. Namun, dengan berkembangnya teknologi komunikasi dan budaya media baru, kemudian berkembang pula budaya tulisan melalui media sosial online.

\section{Fokus Penelitian}

Fokus penelitian ini adalah mengungkap fungsi kedai kopi sebagai ruang publik modern bukan hanya sekedar mengedepankan konsep indoor yang instgramable namun lebih dalam lagi sebagai alasan lahirnya sebuah komunitas seni modern dimana di dalamnya terdapt pertukaran ide melalui aktifitas seni yang mengutakan kebebasan berekpresi yang bebas tekanan apapun. 


\section{B. KERANGKA TEORITIS}

Gagasan mengenai Ruang Publik pertama kali dikemukakan oleh Jurgen Habermas, seorang filsuf Jerman. Dalam bukunya "The Structural Transformation of The Public Sphere; an iquiry into a category of bourgeois society" (1991), Habermas mengkaji ruang publik sebagai ruang dan dunia di mana pendapat menyangkut kebutuhan masyarakakat, dengan bebas tanpa tekanan dan batasan eksternal, dipertukarkan (didiskusikan) oleh orang-orang yang hadir di dalamnya.

Ruang publik borjuis dapat dimengerti, di atas segalanya, sebagai ruang masyarakat privat (sphere of private people) yang berkumpul bersama menjadi sebuah publik. Mereka mengkalim bahwa ruang publik ini diregulasi dari atas guna melawan otoritas publik. Inilah yang lantas menyeret masuk kedalam perdebatan seputar kaidah - kaidah umum yang mengatur hubungan - hubungan di dalam ruang pertukaran komoditas dan ruang kerja sosial yang secara mendasar telah terprivatisasi meski secara publik masih relevan (Habermas, 1989: 41).

Sebelum ruang publik membentuk secara eksplisit fungsi - fungsi politis di dalam medan hubungan antara negara dan masyarakat yang penuh ketegangan, ternyata subjektivitas yang berakar di dalam ruang intim keluarga konjugal telah menciptakan publiknya sendiri. Bahkan sebelum pengendalian terhadap ruang publik oleh otoritas publik ditandingkan, yang akhirnya dimenangkan oleh penalaran kritis manusia - manusia privat mengenai isu - isu politis, sebuah ruang publik dalam bentuknya yang opolitis suudah berkembang di bawahnya lewat perintisan kesusastraan (the literary precursor) mengenai pengoperasian ruang publik di wilayah politis, dia menyediakan lahan pelatihan bagi sebuah refleksi kritis publik yang kala itu masih disibukkan oleh dirinya sendiri sebah proses klarifikasi diri masyarakat privat yang berpusat kepada pengalaman - pengalaman asli keprivatan mereka yang baru. Tentunya, disamping ekonomi politik, psikologi muncul berbagai ilmu borjuis yang khas selama abad ke 18.

Sekitar pertengahan abad ke 17, bukan hanya teh yang popular pertama kali namun juga coklat dan Kopi telah menjadi minuman umum minimal bagi strata populasi Inggris yang berkecukupan. Kedai - Kedai Kopi pertama didikan pada abad tersebut oleh seorang tutor bagi saudagar dari Levantine, namun memasuki dekade pertama abad ke 18, London telah sampai tiga ribu tempat semacam itu, masing - masing dengan pelanggan tetapnya masing masing. Sama seperti Dryden, yang dikelilingi oleh generasi baru para penulis, terlibat dalam pertempuran "kuno lawan modern" di Kedai Kopi Will addicon dan Steele beberapa saat kemudian juga 
memanggil "senat kecil" mereka untuk rapat di Kedai Kopi Button. Begitu pula di Rotary Club yang dikelola oleh sekretaris Kedai Kopi Milton. Fakta bahwa hanya pria saja yang boleh masuk ke lingkungan masyarakat Kedai Kopi mungkin memang bertalian dengan pembentukan salon, seperti perhiasan pada esensinya dilekatkanpada wanita. Kedai Kopi tidak hanya memberikan akses kepada lingkaran - lingkaran relevan yang tidak begitu formal dan lebih mudah dimasuki, namun dia juga memelik strata kelah menengah yang lebih luas, termasuk para perajin dan pegawai pertokoan.

Amerika Serikat sedang dalam proses privatisasi sistem Pendidikan publiknya melalui pencarteran, voucher, kontrak, dan menerapkan Bahasa dan logika berbasis pasar ke dalam kebijakan dan praktik Pendidikan. Doktrin ekonomi neoliberal menyerukan privatisasi barang dan jasa publik, menderegulasi control negara atas modal, tunjangan investasi asing langsung, dan finansialisasi. Dalam prakteknya, kebijakan ekonomi neoliberal memperluas pengeluaran negara pada peran negara yang bersifat menghukum dan represif sementara mengurangi peran pengasuhannya. Kedua partai politik telah menerima sejumlah pengorganisasian nilai-nilai neoliberal termasuk memperlakukan sekolah umum terutama sebagai tenaga kerja dan persiapan konsumen daripada sebagai barang publik yang didedikasikan untuk mempersiapkan warga untuk pemerintahan sendiri kolektif. Mereka juga menolak distribusi sumber daya pendidikan dan desegregasi yang setara demi model "persaingan" berbasis pasar dan "pilihan" di antara sekolah, distrik, dan negara bagian untuk sumber daya yang dibuat langka daripada disediakan berdasarkan kebutuhan. Sama seperti K-12 telah melihat pergeseran radikal menuju mentalitas pasar, ini juga menjadi jelas dalam pendidikan tinggi. Kami telah melihat peningkatan biaya kuliah, program pinjaman berbasis laba, defunding bantuan keuangan, dan kenaikan utang mahasiswa yang sangat tinggi. Beban kerja fakultas telah meningkat karena tenaga kerja akademis telah menjadi lebih "biasa." Program-program humaniora digagalkan karena komposisi bagian ad hoc telah meningkat (Di Leo, Hitchcock, 2016: 30).

Salah satu konsekuensi utama dari perubahan ini adalah pembatasan universitas sebagai tempat yang membantu dan mendukung ranah publik. Gagasan tentang ranah publik dikembangkan oleh Jürgen Habermas dalam Transformasi Struktural Ruang Publik, yang diterbitkan dalam bahasa Jerman pada tahun 1962 dan dalam edisi bahasa Inggris pada tahun 1989. Habermas menjelaskan bahwa ruang publik adalah ruang antara individu dan pemerintah di mana orang-orang berkumpul bersama. debatkan masalah sosial yang penting. Dan pendidikan 
publik - khususnya universitas — adalah salah satu tempat utama yang secara historis menawarkan janji untuk mendorong lingkup publik yang dinamis.

Karena pergeseran ini, para sarjana mulai memperdebatkan matinya "ranah publik" dalam demokrasi AS. Pada tahun 1998 Gerard Hauser, seorang teoretikus terkemuka retorika dan ruang publik, menyatakan, "Di era ketika kepentingan khusus dan negara telah mengurangi politik ke tontonan media massa, dan 'penonton' telah menjadi variabel ekonomi penonton yang diharapkan untuk bertepuk tangan. dan pembelian, pertimbangan saat ini di atas ruang publik memajukan penangkal yang kritis. "6 Kekhawatiran tentang ranah publik berkisar pada gagasan bahwa langkah dari keprihatinan negara bagi warga negara untuk menyatakan dukungan untuk bisnis menyebabkan kerusakan pada gagasan demokrasi. Jika demokrasi bergantung pada musyawarah dan partisipasi sipil, maka ia membutuhkan ruang publik atau ruang di mana konstituen dapat memperdebatkan gagasan, membentuk opini, dan mempengaruhi kebijakan. Ketika proses itu terancam, demikian pula demokrasi. Pada era Reagan, tampaknya banyak kalangan publik telah digantikan oleh kekuatan elit yang diprivatisasi dan berkepentingan khusus yang terutama menganjurkan korporasi.

Seperti halnya Zukin (1996, dalam Barker; 399-401), menyebut ruang publik sebagai tempat terbuka bagi publik (tanpa membedakan status sosial), di mana orang bisa saling bertemu, dan berpartisipasi dalam sebuah budaya yang sama. Dalam setiap budaya, selalu ada sebuah "ruang" sebagai mekanisme untuk lepas dari ritual, rutinitas yang membelenggu. Ruang atau tempat publik merupakan tempat di mana siapapun berhak untuk datang tanpa merasa terasing karena kondisi ekonomi maupun sosialnya.

Tatanan ruang (order) publik merupakan sesuatu yang memiliki ukuran yang tepat, semua bagian harus cocok dengan bagian lain. Beberapa kriteria ruang publik secara esensial ada tiga macam yaitu:

a) Dapat memberikan makna atau arti bagi masyarakat setempat secara individual maupun kelompok (meaningful).

b) Tanggap terhadap semua keinginan pengguna da dapat mengakomodir kegiatan yang ada pada ruang publik tersebut (responsive).

c) Dapat menerima kehadiran berbagai lapisan masyarakat dengan bebas tanpa ada deskriminasi. 
Kemudian seiring dengan bertumbuh kembangnya ruang public, ruang ini kemudian dimanfaatkan oleh pihak swasta dan privat sebagai bagian dari komersialisasi. Meskipun banyak kritik dan sikap skeptik ditujukan terhadapnya, konsep ruang publik tetap menjadi tumpuan harapan untuk membela kebebasan individu dan pluralism dalam masyarakat modern.

Selain sebagai ruang bertemu, berinteraksi, serta wadah berkegiatan sosial lainnya, ruang publik juga memiliki fungsi yang terkadang tidak disadari dan akhirnya sering diabaikan. Padahal, manfaatnya dapat memberi keuntungan yang dapat memajukan kualitas hidup masyarakat atau komunitas yang tinggal di sekitar ruang publik tersebut.

Salah satunya yaitu jika sebuah ruang publik dimanfaatkan, dijaga, dan diatur secara kreatif sesungguhnya dapat menjadi bisnis yang menguntungkan. Karena ruang publik yang berhasil dapat mendorong naik harga sewa bangunan, dan ruang publik yang aktif dan berhasil telah terbukti menaikkan nilai property bagi bangunan di sekitarnya serta menciptakan efek positif untuk jangka waktu yang panjang.

Kemudian teori - teori mengenai kependudukan (citizenship) yang banyak berkembang dalam mendefinisikan dan memahami peran sebuah ruang publik. Graham Murdock, mengemukakan sebuah teori dan mengidentifikasi apa yang ia lihat dan sebagai empat hak yang timbul dari kehadiran sebuah ruang publik:

1. Hak mendapatkan informasi, menciptakan kemampuan untuk mengakses informasi seluas - luasnya mengenai aktivitas akan meluaskan pilihan dalam berkegiatan, medapatkan motivasi, dan strategi dalam hidup kita. Selain itu juga dapat mendapatkan akses yang mudah ke berbagai institusi, serta orang - orang yang berhubungan langsung dengan kondisi ekonomi, sosial, dan politik yang mempengaruhi lingkungan kita.

2. Hak mendapatkan pengalaman, menyediakan akses untuk menyampaikan representasi individual maupun pengalaman sosial, mendengarkan dan berbagi cerita dapat memotivasi sense of self belonging dan mampu menghubungakan apa yang disebut dengan 'reciprocities of full citizenship'.

3. Hak mendapatkan pengetahuan, kita membutuhkan lebih banyak informasi, kita membutuhkan kemampuan untuk dapat mengenali latar belakang sesuatu, memahami dan mengartikan informasi dan pengalaman ke dalam pengetahuan yang menghubungkkan waktu sekarang dengan masa lampau serta ikut membangun 
strategi untuk masa depan. Ruang publik harus menjamin akses menuju 'kunci perdebatan dan argumen'.

4. Hak untuk berpartisipasi, mencakup kemampuan berbicara tentang hidup dan aspirasi dan didengar oleh orang lain. Aman dalam memperhatikan perbedaan - perbedaan yang kita miliki, mengekspresikan ketidakpuasan dalam suatu hal direpresentasikan dalam masyarakat.

\section{Sejarah Minum Kopi}

Di era sekarang kedai kopi adalah sebuah rumah nyaman tempat kita menikmati bercangkir - cangkir kopi kesukaan. Coffee shop dibuat dengan kenyamanan dan didesain dengan konsep menarik yang membuat pengunjung tak hanya menikmati kopi tetapi juga melebur dalam suasana yang melingkupinya. Tapi tak banyak yang tau, jauh sebelum kedai kopi nyaman yang tak lepas dari WiFi dan mesin espresso paling canggih, kedai kopi mengalami evolusi dari zaman ke zaman. Sejarah kedai kopi telah ada sejak zaman dahulu. Melebar dan melebur menjadi budaya dan ritual manusia dalam cangkir - cangkir kopi.

Kedai kopi pertama di dunia yang tercatat diketahui muncul pada 1475. Kedai kopi ini bernama Kiva Han dan berada di kota Konstatinopel (sekarang Istanbul) Turki. Kedai kopi ini diketahui menjadi Coffee Shop pertama yang buka dan melayani pengunjungnya dengan kopi khas Turki.

Ide minum kopi pertama dengan krim dan gula awalnya ada di Eropa pada 1529 dan ini adalah waktu yang sama saat kedai pertama di Eropa didirikan. Adalah Franz Georg Kolschitzky membuka sebuah kedai kopi yang diketahui sebagai kedai kopi pertama di Eropa. Kolschitzky ternyata dulu pernah tinggal di Turki dan dia merupakan satu - satunya orang di Wina yang mengetahui betapa berharganya biji kopi mengingat tidak popularnya pada masa itu.

Di kedai kopinya ini Kolschitzky memperkenalkan gagasan minum kopi dengan menggunakan penyaring dan juga menikmati kopi dengan susu dengan gula. Minuman yang digagas Kolschitzky ini mendapat sambutan baik dan sejak itu mulailah bermunculan kedai kedai kopi yang tak hanya menjual kopi tetapi juga makanan manis sebagai teman minum kopi. Pada masa itu popularitas kopi merebak dan berkembang hingga ke Inggris.

Sejarah kopi di Indonesia dimulai empat abad lalu, ketika India mengirimkan bibit kopi Yemen atau yang dikenal dengan Arabica kepada pemerintah Belanda di Batavia pada tahun 
1696. Namun bibit pertama tersebut gagal tumbuh karena terjadi banjir di Jakarta (Batavia), kemudian pengiriman ke 2 sukses. Benih biji kopi tersebut tumbuh di Indonesia, pada tahun 1711 biji - biji dikirim ke Eropa. Dalam kurun waktu 10 tahun, pengiriman kopi meningkat hingga 60 ton pertahun. Indonesia saat itu telah menjadi daerah perkebunan kopi selain di luar Arab dan Ethiopia.

\section{METODE PENELITIAN}

Penelitian ini menjadikan Kedai Kopi Suguh sebagai subjek penelitian dan perannya dalam membentuk komunitas seni Hypseed sebagai objek penelitian. Penelitian ini berlokasi di Jakarta Barat dengan memperhatikan mereka yang dapat dijadikan sebagai informan kunci (key informan) yang dapat memberikan penjelasan yang memadai.

Penelitian ini menggunakan pendekatan subyektif dengan perspektif interpretif dengan menggunakan metode penelitian fenomenologi. Pada penelitian fenomenologi pengumpulan data dilakukan dengan menggunakan wawancara mendalam. Metode wawancara mendalam ini merupakan esensi dari fenomena yang diamati dan dapat diceritakan dari sudut pandang orang pertama yaitu orang yang mengalaminya langsung.

Pendekatan subyektif erat dengan istilah fenomenologi sebagai istilah generik yang merujuk kepada semua pandangan ilmu sosial yang menempatkan kesadaran manusia dan makna subyektifnya sebagai fokus untuk memahami tindakan sosial.

Dikutip dari Agustina Zubair, Littlejohn and Foss (2005:204) mengungkapkan bahwa tardisi fenomenologi berpusat pada pengalaman kesadaran seseorang. Teori-teori dalam tradisi ini mengasumsikan bahwa manusia secara aktif menginterpretasikan pengalaman mereka dan memahami dunia mereka dengan cara mengalaminya secara pribadi. Subjek dalam penelitian ini adalah tiga orang sebagai informan, yaitu Jefri, pemilik Kedai Kopi Suguh, Dhany, Pemilik Artspace Leitstar dan Edwin, Ketua Komunitas Seni Hypeseed.

\section{PEMBAHASAN}

Penelitian ini menemukan bahwa kedai kopi suguh berperan dalam terbentuknya ruang sosial seni dan budaya. Peran kedai kopi sebagai ruang publik, sebagai tempat berkumpul dijelaskan oleh pemiliki Kedai Suguh Kopi, Jefri. Menurutnya tujuan awal mendirikan kedai 
kopi adalah untuk mengembalikan makna minum kopi yang sebenarnya yaitu kopi sebagai teman berdiskusi.

“Tujuan saya membuat Suguh Kopi adalah untuk memulai berbisnis sendiri saat itu, dan juga saya ingin mengembalikan makna minum kopi yang sebelumnya. Yaitu awalnya minum kopi memiliki makna sebagai teman untuk berdiskusi, berbincang, bertukar fikiran dan kegiatan komunikasi lainnya. Memang pada saat itu sudah mulai bermunculan kedai kopi, namun mereka hanya menampilkan konsep kedainya mengarah kepada lifestyle/sekedar bergaya saja. Untuk apa yang membedakan Suguh Kopi dengan kedai lainnya, sesuai dengan makna dari namanya Suguh Kopi bukan hanya sekedar menyuguhkan segelas kopi, namun kita juga menyuguhkan suasana yang nyaman untuk berdiskusi dan menikmati kopi yang dibuat baristanya. Selain itu Suguh Kopi juga terbuka untuk para konsumennya yang ingin berdiskusi dengan baristanya, jika konsumen tersebut ingin mengenal kopi lebih atau hanya sekedar berdiskusi mengenai keminatan masing-masing. Yah, pokoknya Suguh Kopi terbuka untuk mereka yang memang ingin memperbaiki komunikasi satu sama lain, baik dengan kelompoknya, maupun dengan orang lain yang sedang ada di Suguh Kopi tersebut. Yang penting tujuan awal saya untuk mengembalikan makna minum kopi dapat terwujud melalui adanya Suguh Kopi di Leitstar”.

Ruang Publik yang sudah terbentuk di Suguh Kopi memiliki peran yang cukup berpengaruh dalam proses terbentuknya komunitas di Suguh Kopi. Salah satu komunitas tersebut adalah Hypseed. Terbentuknya Hypseed menjadi sebuah komunitas yang bergerak dibidang seni visual tidak luput dari peran Suguh Kopi sebagai penyedia tempat untuk mereka berkumpul, berdiskusi, dan melakukan aktivitas komunikasi lainnya.

Menurut Edwin, ketua komunitas Hypeseed, Di Suguh Kopi, mereka diberi kebebasan berekspresi. Komunitas ini aktif menyelenggarakan sharing session setiap minggunya bertempat di Suguh Kopi.

"Suguh Kopi sangat penting untuk Hypseed karena mereka alasan saya membentuk Hypseed dan mereka juga menyediakan tempat untuk komunitas. Kami bisa mengadakan acara setiap minggunya yaitu sharing season, dan terlepas dari itu Leitstar juga penting karena Leitstar memberikan kebebasan bagi para member Hypseed untuk terus 
berkembang dan memberikan kebebasan terhadap komunitas ini untuk terus berkarya, karena bagi Leitstar selama komunitas ini terus berkembang Leitstar akan selalu mendukung komunitas ini dan di ruang lingkup Suguh Kopi komunitas ini sangat dapat kebebasan mulai dari kebebasan dalam berkarya, berbicara, berpendapat, dan itu yang membuat anggota dari komunitas Hypseed ini jadi betah untuk berlama-lama di Suguh Kopi”.

Penelitian ini mengungkap bahwa fungsi ruang publik tidak akan terwujud jika pemilik Leitstar tidak membentuk art space. Keberadaan Suguh Kopi sebagai bagian dari ruang public menimbulkan empat jenis hak:

\section{1) Hak mendapatkan informasi}

Pada rangkaian hak yang pertama dalam proses ruang publik terdapat beberapa kriteria didalamnya yaitu, kebebasan berpendapat, kebebasan berbicara, kebebasan pers, kebebasan berkumpul, dan kebebasan berkelompok.

"Adapun tujuan lain dari Suguh Kopi bergabung didalam lingkungan Leitstar adalah untuk menyediakan tempat dimana itu para pelanggan bisa berdiskusi sambil menikmati kopi, dengan tidak adanya batasan-batasan tertulis tentang suatu pembahasan atau diskusi dan kita memberikan kebebasan bagi mereka untuk membahas apapun, baik itu seni, agama, politik, dll nya yang penting itu lebih kearah positif".

Suguh Kopi sudah dirancang, dan disesuaikan untuk mendukung serta memberikan kebebasan untuk konsumennya melakukan kegiatan apapun selagi masih dalam ruang lingkup yang positif. Dimana itu sudah mencakup beberapa kriteria dari rangkaian hak pertama yaitu kebebasan berpendapat, berbicara, berkumpul, dan kebebasan berkelompok. Adapun satu kriteria lagi dalam rangkaian hak pertama yakni kebebasan pers.

“Terkadang juga yang datang di Suguh Kopi beberapa ada yang dari media dan mereka juga berdikusi kepada saya tentang pendapat saya dengan pers dan media, dan saya menikmati itu karena saya bisa open dengan berbagai macam kalangan." (Dhany, pemilik Leitstar)

2) Hak Kedua, Hak Kebebasan Pribadi 
Pada rangkaian hak yang kedua dalam proses ruang publik terdapat beberapa kriteria didalamnya yaitu kebebasan pribadi dan kedamaian dirumah dan sebagainya.

"Sebelum terbentuk acara living room seperti sekarang tempat ini eksklusif tapi setelah itu saya merasa bahwa sebagai bisnis saya kurang berkembang tapi yang lebih parah lagi untuk saya adalah saya merasa kurang berkembang sebagai manusia karena saya merasa kurang dalam berdiskusi dengan orang lain karena dia masih marasa eksklusif dan hanya mau berdikusi dengan yang satu paham dengan dia sehingga kurangnya toleransi, kurang kebebasan dalam berbicara, serta dalam berpendapat".

Leitstar di sini turut berperan dalam membentuk ruang publik. Dimana sebelum Suguh Kopi bergabung dengan Leitstar, Dhany, sang pemilik, merasa belum memiliki kebebasan pribadi karena saat itu dia mempunyai prinsip rumahnya hanya untuk orangorang tertentu saja. Hingga akhirnya dia merasa perlu mengembangkan dirinya dengan mengajak Suguh Kopi untuk bergabung dengan Leitstar, sehingga ia dapat bertemu, berdiskusi, dan terwujudlah kebebasan pribadinya, serta merasa memiliki kedamaian dirumah.

"Setelah Suguh Kopi bergabung dengan Leitstar, saya mulai berfikir untuk menggabungkan ide kopi dengan artspace istilahnya yaudah yang Suguh Kopi butuh kan adalah pelanggan tetap, dan yang saya butuh adalah seniman, why not kita bikin dari awal biarpun pelan tapi komunitas seni yang offline bukan online atau sosial media. Karena saat ini banyak komunitas rata-rata bergerak di sosial media (online), jadi kita harus berani untuk beda dari yang sekarang sedang happening. Kita nggak menghalangi dia untuk aktif di sosial media (online), akan tetapi akan lebih terasa feedbacknya untuk kita, salah satunya yaitu membuat ruang diskusi. Nah cuman kan engga semudah itu di bikin kan yaudah pertamatama gua mutusin untuk cari leader orang yang paling engga mau mengorbankan waktunya untuk membangun wadah itu. Seperti yang sudah tergabung salah satunya yang ada disini tuh komunitas gambar (Hypseed)". (Dhany, Pemilik Leitstar)

3) Rangkaian Hak Ketiga 
Pada rangkaian hak yang ketiga dalam proses ruang publik terdapat beberapa kriteria didalamnya yaitu Kesetaraan terhadap hukum, dan pelindungan terhadap property dan sebagainya. Dhany melakukan perubahan besar pada konsep awal yaitu ekslusifitas. Pada tahun 2016 itu ia sudah memiliki studio dan sudah ada acara living room dan ruang tamu juga sudah siap serta sudah ada studio recording tapi ia merasa masih ada yang kurang. Merasa ingin selalu terhubung dengan orang lain, ingin mendengarkan banyak orang, ia memutuskan ingin menjadi fasilitator.

"Jadi saya mundur lagi kearah saya mau mendengarkan orang lebih banyak lagi, gimana nih caranya dan akhirnya saya mengumpulkan teman-teman yang dimana mereka bisa mensuport ide-ide saya. Setelah itu saya mulai berfikir kalo Jefri mau untuk berkerjasama, saya akan menempatkan letak mereka di bagian dari garasi. Awalnya garasi tersebut saya mau jadikan sebuah toko musik tapi kalo itu dijadikan toko musik nanti yang datang kesini ujung-ujungnya musisi - musisi lagi, tapi kalau kedai kopi pastinya nanti yang datang kesini dari berbagai macam kalangan”.

Dhany mengaku sejak Suguh Kopi bergabung, selama 2 tahun ini mulai ada orang-orang yang tidak ia kenal dan beberapa juga bukan penikmat seni tapi lama kelamaan menjadi suka seni.

“Terkadang ada juga yang bertanya, 'wih di dalem ada apa bang?', terus saya bilang kalo di dalem itu ada tempat untuk perform', setelah itu mulailah terjalin hubungan, baik itu bisnis atau cuman sekedar berdikusi bertukar pikiran baik itu tentang politik, agama, atau sosial budaya Indonesia dan setelah itu disini kebebasan berpendapat, berbicara serta berkumpul pun mulai terbangun”.

Kondisi ini sangat jauh berbeda dari tahun 2008 yang pada saat itu Dhany hanya mau rumahnya tersebut tertutup (eksklusif) untuk kalangan terbatas yang dikenalnya. Ia mengaku setelah Suguh Kopi bergabung terkadang ada beberapa pengunjung yang datang dari media. Diskusi seputar pers dan media bergulir. Dhany, secara personal mengungkapkan bahwa ini adalah hal yang positif.

"Saya menikmati itu karena saya bisa open dengan berbagai macam kalangan. Setelah itu saya mencoba untuk mengaktifkan komunitas - komunitas baru untuk 
sharing session di wilayah suguh setiap minggunya sehingga bisa makin banyak orang yang mengenal tempat ini dan si suguh ini”.

Dhany merasa dirinya dapat berkenalan dengan berbagai macam kalangan masyarakat. Tanpa dibatasi dengan adanya ras, suku, agama, maupun keminatan yang berbeda. Selain itu, juga menjadi Fasilitator dengan mengajak Suguh Kopi untuk bergabung, dan menempatkan kedai Suguh Kopi di garasi rumahnya.

"Mungkin dari segi obrolan dan tempat serta kualitas minuman yang suguh kopi berikan terhadap mereka yang membuat mereka betah berlama lama berada di kedai ini dan ramah tamah kita sebagai penyedia tempat serta para barista terhadap orang yang datang ke tempat ini, dan disini tidak ada batasan - batasan tertulis tentang suatu pembahasan atau diskusi dan kita memberikan kebebasan bagi mereka untuk membahas apapun, baik itu seni, agama, politik, dll nya yang penting itu lebih kearah positif"

Suguh Kopi membebaskan pelanggannya untuk berdiskusi dan membahas hal apapun tanpa memandang ras, suku, agama dan lainnya, dengan alasan masih dalam ranah yang positif. Dengan adanya Ruang Publik di Suguh Kopi membuat para pelaku dan komunitas seni merasa lebih bebas untuk menggali, mencari, membuat, melakukan kegiatan yang positif untuk mengisi waktu luang maupun mengasah kemampuan seni yang sudah mereka tekuni sebelumnya.

"Suguh Kopi sangat penting untuk Hypseed karena mereka alasan gua membentuk Hypseed dan mereka juga menyediakan tempat untuk komunitas gua bisa mengadakan acara setiap minggunya yaitu sharing session."

Komunitas Hypseed didukung oleh pihak Suguh Kopi dan Leitstar mulai dari fasilitas yang diberikan kepada mereka untuk mereka melakukan aktifitas komunitasnya tersebut, dan mendapatkan respon yang baik pula dari para member komunitas tersebut dengan makin banyaknya orang baru yang ingin bergabung dengan Hypseed. Karena bagi komunitas tersebut yang mereka butuhkan adalah dukungan dari segi fasilitas dan kebebasan mereka untuk menuangkan pikiran, ide dan hasrat mereka dalam sebuah seni visual.

\section{E. KESIMPULAN}


Berdasarkan analisa yang peneliti lakukan setelah peneliti melakukan wawancara secara mendalam terhadap tiga narasumber yaitu Dhany, Jefri, dan Edwin mengenai kedai kopi sebagai ruang publik modern, dapat dibuat kesimpulan bahwa:

1. Terbentuknya Ruang Publik di Suguh Kopi adalah hasil dari pemikiran saudara Dhany sebagai pemilik Leitstar. Disini peran saudara Dhany sebagai fasilitator untuk Suguh Kopi dan komunitas , sudah dirancang olehnya.

2. Ruang publik yang terbentuk di Suguh Kopi memiliki peran dalam proses terbentuknya komunitas seni Hypseed.

3. Dengan adanya Ruang Publik di Suguh Kopi membuat para pelaku dan komunitas seni merasa lebih bebas untuk menggali, mencari, membuat, melakukan kegiatan yang positif untuk mengisi waktu luang maupun mengasah kemampuan seni yang sudah mereka tekuni sebelumnya.

4. Dukungan pada Komunitas Hypseed terlihat dari fasilitas yang diberikan kepada mereka untuk mereka melakukan aktifitas komunitasnya tersebut, dan mendapatkan respon yang baik pula dari para member komunitas tersebut dengan makin banyaknya orang baru yang ingin bergabung dengan Hypseed.

\section{DAFTAR PUSTAKA}

Al Fairusy, M. S. (2008). Public Sphere Dalam Secangkir Kopi (Meneropong ruang publik dan produksi wacana di warung kopi Aceh). Jurnal Online Aceh Institute.

Bungin, B. (2003). Analisis data Penelitian Kualitatif: Pemahaman Filosofi dan Metodelogis ke Arah Penguasaan Model Aplikasi. Jakarta: Rajagrafindo Persada.

Bungin, B. (2007). Penelitian Kualitatif. Komunikasi, kebijakan public dan ilmu sosial lainnya, Jakarta, Kencana.

Deddy, M. (2003). Metodologi Penelitian Kualitatif. Bandung, PT. Remaja Rosdakarya.

Di Leo, J. R., \& Hitchcock, P. (Eds.). (2016). The New Public Intellectual: Politics, Theory, and the Public Sphere. Springer.

Drs. Sutaryo, M.Si. Sosiologi Komunikasi, Perspektif Teoritik. Yogyakarta 2005

Habermas, J. (1989). Ruang Publik, Sebuah Kajian Tentang Kategori Masyarakat Borjuis.

Hardiman, F. B. (2010). Ruang Publik: Melacak "Partisipasi Demokratis" dari Polis sampai Cyberspace. Kanisius Yogyakarta. 
Hidayat, D. (2003). Paradigma dan Metodologi Penelitian Sosial Empirik Klasik, Jakarta. Departemen Ilmu Komunikasi FISIP, Universitas Indonesia.

Idrus, M. (2009). Metode Penelitian Ilmu Sosial. Jakarta: Erlangga.

Kriyantono, R. (2012). Teknik Praktis Riset Komunikasi. Jakarta, PT Kencana Prenada Media Group.

Moleong, L. J. (2006). Metode Penelitian Kualitatif. Bandung: Remaja Rosdakarya.

Nazir, M. (2009). Metode Penelitian. Jakarta. Ghalia Indonesia.

Negt, O., Kluge, A. (1988). Public Sphere and Experience. Toward an Analysis of the Bourgeois and Proletarian Public Sphere. MIT Press.

Prihutami, D. (2008). "Ruang Publik Kota yang Berhasil." (Skripsi). Jakarta: Universitas Indonesia.

Purnamasari, A. (2012). "Kajian Spasial Ruang Publik (Public Space) Perkotaan Untuk Aktivitas Demonstrasi Mahasiswa Di Kota Makassar." Jurnal Bumi Indonesia 1, no. 2.

Ruslan, R. (2010). Metode Penelitian Public Relations dan Komunikasi Jakarta: PT.Graha Grafindo Persada

Santoso, H. (2009). Persepsi Mahasiswa Terhadap Ruang Komunal Sebagai Tempat Interaksi Sosial (Studi Kasus: Fakultas Ilmu Pendidikan UNNES)(Doctoral dissertation, Universitas Negeri Semarang).

Sugiyono. (2007). Metode Penelitian Pendidikan Pendekatan Kuantitatif, Kualitatif, dan R\&D. Bandung: Alfabeta

Tahir, M. (2011). Pengantar Metodologi Penelitian. Makassar.

Wijayanti, S. (2000). Pola Seting Ruang Komunal Interaksi Sosial Mahasiswa Studi Kasus Aritektur Fakultas Teknik UNDIP.

Zainal, A. (2012). Penelitian Pendidikan. Bandung.

Zubair, A., (2013). Presentasi Diri Etnik Cina Bangka dalam Hubungan Bisnis dengan Etnik Melayu Bangka, Jurnal Aspikom, Vol 1, No 6. 